\title{
LC/QTOF-MSによるフィルグラスチムバイオ後続品の定性・成分分析
}

\author{
松村健吾 ${ }^{1,2}$, 大谷祐基 ${ }^{1}$, 大村友博 ${ }^{1}$, 米澤 淳 $^{1}$, 津田真弘 ${ }^{1}$, 池見泰明 ${ }^{1}$

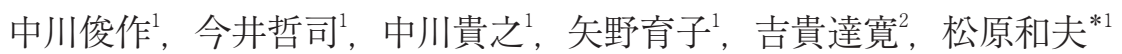 \\ 京都大学医学部附属病院薬剂部 ${ }^{1}$, 京都薬科大学臨床腫瘍学分野 ${ }^{2}$
}

\section{Qualitative Component Analysis of Filgrastim Biosimilars by LC/QTOF-MS}

\author{
Kengo Matsumura, ${ }^{1,2}$, Yuki Otani ${ }^{1}$, Tomohiro Omura ${ }^{1}$, Atsushi Yonezawa', \\ Masahiro Tsuda ${ }^{1}$, Yasuaki Ikemi ${ }^{1}$, Shunsaku Nakagawa ${ }^{1}$, Satoshi Imai', \\ Takayuki Nakagawa ${ }^{1}$, Ikuko Yano, Tatsuhiro Yoshiki ${ }^{2}$ and Kazuo Matsubara*1 \\ Department of Clinical Pharmacology and Therapeutics, Kyoto University Hospital ${ }^{1}$, \\ Department of Clinical Oncology, Kyoto Pharmaceutical University ${ }^{2}$ \\ $\left[\begin{array}{l}\text { Received March 18, } 2016 \\ \text { Accepted July 6, } 2016\end{array}\right]$
}

Many biosimilars have been launched recently, however, a precise analytical method to evaluate their characteristics has not been developed. In this study, we established a new qualitative analysis technology for biomedicines using liquid chromatography coupled with quadrupole time-of-flight mass spectrometer (LC/QTOF-MS), and assessed the original product and 4 biosimilars of filgrastim. Three peaks (Peak 1-3) appeared in total ion chromatogram by LC/QTOF-MS in the original brand-named drug. Filgrastim appeared as the main peak (Peak 1), and its molecular weight was calculated to be $18798.96 \pm 0.02$. When the original product was reduced by dithiothreitol, the molecular weight was $18802.19 \pm 0.47$, which was identical to the theoretical value based on amino acid sequence. These results indicate that it is possible to measure and distinguish molecular weights of untreated and reduced forms of filgrastim by LC/QTOF-MS. In addition, main peaks from all products including biosimilars showed exactly the same mass spectra and calculated molecular weights, suggesting that the main components (filgrastim) in these 4 products were considered to be qualitatively equal. On the other hand, the area ratios of 2 secondary peaks (Peaks 2 and 3) against the main peak (Peak 1) in 2 biosimilars were higher than those in the original product. The calculated molecular weights in Peaks 2 and 3 corresponded to that of polysorbate 80, which was one of the additives in the formulation. In conclusion, LC/QTOF-MS is a useful technique for qualitative component analysis of biomedicines.

Key words — filgrastim, biosimilar, liquid chromatography coupled to quadrupole time-of-flight mass spectrometry, qualitative analysis

\section{緒言}

バイオ医薬品の開発は，遺伝子組換え技術の向 上と共に近年飛躍的な成長を遂げている.一方で, バイオ医薬品の開発には莫大な費用がかかり, 薬 価が高額であることから，患者への経済的負担や 医療費の増大が課題となっている。このような社 会的背景に伴いバイオ後続品の開発も数多く進ん でいる，バイオ後続品とは，「国内で既に新有効
成分含有医薬品として承認されたバイオテクノロ ジー応用医薬品（先行バイオ医薬品）と同等／同 質の品質, 安全性, 有効性を有する医薬品として, 異なる製造販売業者により開発される医薬品」と 定義されており, ${ }^{1} 2016$ 年 3 月現在, 本邦ではイ ンスリン, ソマトロピン, エポエチンアルファ, フィルグラスチム, インフリキシマブのバイオ後 続品が承認されている. バイオ後続品は, 先行品 の特許期間が終了後に発売される点については後

\footnotetext{
*テ606-8507 京都市左京区聖護院川原町54
} 
発医薬品と同様であり，国が施策として進める医 療費削減にも貢献する可能性が詔われている (http://www5.cao.go.jp/keizai-shimon/kaigi/cabinet/ 2015/decision0630.html， 2016 年 3 月 18 日; http:// www.mhlw.go.jp/stf/seisakunitsuite/bunya/kenkou_ iryou/iryou/kouhatu-iyaku/, 2016年 3 月18日). バイ オ後続品分野で先行している欧州では, 2006 年 にバイオ後続品（欧州および米国ではバイオシミ ラーと呼ぶ）として初めてソマトロピン（遺伝子 組換え) が承認され，2015 年 8 月現在，6 種類 19 製剤のバイオ後続品が承認されている，また，米 国においても2015 年 3 月にバイオ後続品として 初めてフィルグラスチムが承認された，今後，ま すますバイオ後続品は市場シェアを拡大すると考 えられる。

高分子化合物であるバイオ医薬品は，製造工程 において細胞培養技術を用いるため, アミノ酸配 列は同じであるが, 糖鎖付加や酸化等の修飾が異 なる複数の構造体からなる. ${ }^{2)}$ 従って, 低分子化 合物である後発医薬品と異なってバイオ後続品は 先行バイオ医薬品と全く同じ物を製造することが できない，そのため，バイオ後続品の製造販売承 認要件は先行バイオ医薬品に準ずる厳格な条件 （非臨床試験として薬理試験，毒性試験，臨床試 験として薬物動態・薬力学試験, 有効性評価, 安

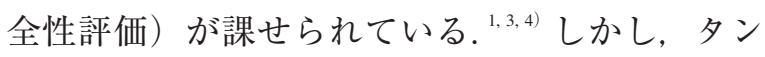
パク質への糖鎖付加やリン酸化などの修飾やその 立体構造に関する情報はそしい。

第十六改正日本薬局方では, フィルグラスチム （遺伝子組換え）の確認試験は sodium dodecyl sulfate（SDS）ポリアクリルアミドゲル電気泳動法 と液体クロマトグラフィー法, 純度試験として液体 クロマトグラフィーによる試験法が記載されてお り, 5) バイオ後続品でもそれに準じた試験が行われ ている. バイオ医薬品のような高分子化合物の場 合, 高次構造の変化や糖鎖修飾などが薬効に影響 を与えることが知られており, 6,7 一次構造の変化(糖 鎖修飾，アセチル化等）について精密質量分析計 などを用いて簡便に解析することができれば，製 剤学的な品質を担保できる有用なツールとなり得 る. そこで我々は, 現在日本で使用されているバイ オ後続品のなかで最も多くの製郕が承認されてい
るフィルグラスチムを例に取り, 近年性能の進歩が 著しい四重極飛行時間型質量分析計 (LC/QTOFMS）を用いてその定性・成分分析法（LC/QTOFMS 法) について検討し, フィルグラスチム先行品 とバイオ後続品の成分について比較を行った.

\section{方 法}

\section{1. 試料}

フィルグラスチム（遺伝子組換え）注射液は, 2012 年に 1 製剤， 2013 年に 1 製郕（これら 2 製 剤は 2 社ずつが共同販売という形をとっている), 2014年にも 1 製郕が承認されている. 試料として, 本邦で承認されているフィルグラスチム先行品 （先行品）および 2013 年 5 月末時点で国内承認さ れているフィルグラスチムバイオ後続品 4 製剤 （製品 $\mathrm{A} 〜 \mathrm{D}$ とする）を希釈せずに用いた.

\section{2. 還元処理}

試料にジチオトレイトール（dithiothreitol: DTT, ナカライテスク(株), 京都) を添加して終濃度 $1 \mathrm{mM}$ にし, $37^{\circ} \mathrm{C} て ゙ ~ 45$ 分反応させた。 その後 $2 \%$ キ酸を用いて反応を停止させ，分析を行った。

\section{LC/QTOF-MS 分析}

測定機器には Agilent 6550 iFunnel Q-TOF LC/MS システム (Agilent Technologies, Santa Clara, USA) を用いて，カラムはZZORBAX 300SB-C18 $2.1 \times 50$ $\mathrm{mm}$ （粒子径 $3.5 \mu \mathrm{m}$ : Agilent Technologies）を使用 した。移動相は $0.1 \%$ ギ酸水溶液 $(\mathrm{A})$ とアセトニ トリル $(\mathrm{B})$ のグラジュエント混液（B％0-10分： $0 \rightarrow 10 \%, 10-12$ 分：10 $\rightarrow 90 \%, 12-12.1$ 分： $90 \rightarrow 10 \%$ ）とし, 流速を $0.3 \mathrm{~mL} / \mathrm{min}$, カラム温度 は $40^{\circ} \mathrm{C}$ とたた. QTOF-MS システムは以下の条件 に設定して測定を行った. ポジティブモード, Drying gas $\left(\mathrm{N}_{2}\right): 12 \mathrm{~L} / \mathrm{min}, 350^{\circ} \mathrm{C}$, Sheath gas $: 12$ $\mathrm{L} / \mathrm{min}, 400^{\circ} \mathrm{C}$, Nebulizer gas : $60 \mathrm{psig}$, Capillary : $3500 \mathrm{~V}$, Skimmer : $65 \mathrm{~V}$, Octopole RF : $750 \mathrm{~V}$, Fragmentor：350 V（高分子量測定モード, $\mathrm{m} / \mathrm{z}$ ： 300-3200)，100 V（低分子量測定モード, $\mathrm{m} / \mathrm{z}$ ： 100-1700)。質量の補正には $\mathrm{m} / \mathrm{z}: 921$ および 1221 （HP-921 and HP-1221, Agilent Technologies）を用いた. 


\section{4. データ処理}

多価イオン高分子で特徵的な複数の $\mathrm{m} / \mathrm{z}$ のピー クからなるマススペクトルに基づきゼロ電荷スペ クトルである質量を計算するデコンボリューショ ンおよび面積を求める自動積分は, Agilent Mass Hunter（Agilent Technologies）を使用し, Maximum Entropy 法で算出した．先行品とバイオ後続品に おける含有成分比の比較には Dunnett の多重比較 検定を用い，有意水準 5\%未満で有意差があるも のとし，差の信頼区間は $95 \%$ とした. ${ }^{8}$ 測定機器 の再現性と正確性の評価には二元配置の分散分析 を用いて評価した。

\section{結果}

\section{1. 測定機器の再現性と正確性の評価}

測定機器の再現性と正確性を担保するため，先 行品を1日 5 回（Time A $\sim \mathrm{E}$ ), 4 日間（Day 1〜4） 測定し，主成分フィルグラスチムのピークに関し て, 求められる質量について日間変動および日内 変動の確認を行った。その結果, 因子が時間もし くは日のどちらの場合においても測定質量に差は 認められなかった（表 1).

\section{2. 還元処理}

フィルグラスチムは分子内にジスルフィド結合 を2つ持つ（図 1). LC/QTOF-MS が，還元処理 前後での質量差を検出できるか否か検討するた め，未処理の試料および DTTによる還元処理後 の試料について, 主成分の質量を算出した. 表 2 に示す通り, 還元処理した試料では, 理論質量值 と同等の值が算出されることを確認した。

\section{3. 先行品およびバイオ後続品の比較解析}

先行品およびバイオ後続品 (バイオ後続品 $\mathrm{A} \sim \mathrm{D}$ ) について測定質量に違いの有無を検証するため, 無処理で LC/QTOF-MS による質量分析を行った (図 2).すずての製品において，トータルイオンク

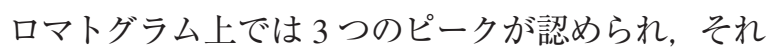

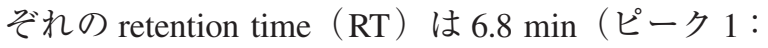
主成分ピーク), $8.6 \mathrm{~min}$ (ピーク $2:$ 副次ピーク), 9.3 $\min (ヒ ゚ ー ク 3:$ 副次ピーク）であった（図 2A）. 本研究では別ロットを用いて比較したが，ロット間 での差は認められなかった(data not shown)。また, 主成分のピーク面積は, バイオ後続品 $\mathrm{A} \sim \mathrm{D}$ にお いて先行品とほぼ同等であった，一方, 副次ピー ク面積は, バイオ後続品 $\mathrm{C}, \mathrm{D}$ については先行品 とほぼ同等であったが, バイオ後続品 $\mathrm{A}, \mathrm{B}$ につ いては先行品と比較してピーク面積が大きかった.

次に, ピーク 1 に扔けるマススペクトルを作成 したところ, 先行品, バイオ後続品 $\mathrm{A} \sim \mathrm{D}$ のすべ ての製品においてスペクトルは同様の結果となっ た（図 2B）。さらに, デコンボリューションにより 測定質量を算出した結果，バイオ後続品 $\mathrm{A} \sim \mathrm{D}$ の 測定質量は先行品と同じ 18798 となった（図 2C).

MTPLGPASSL PQSFLLKCLE QVRKIQGDGA ALQEKLCATY KLCHPEELVL LGHSLGIPWA PLSSCPSQAL QLAGCLSQLH SGLFLYQGLL QALEGISPEL GPTLDTLQLD VADFATTIWQ QMEELGMAPA LQPTQGAMPA FASAFQRRAG GVLVASHLQS FLEVSYRVLR HLAQP

図1 フィルグラスチムのアミノ酸構造 (実線：ジスルフィド結合)

表 1 測定機器の再現性と正確性

\begin{tabular}{|c|c|c|c|c|c|c|c|}
\hline & 因子 & 例数 & 測定質量 & 自由度 & 平均平方 & F值 & $P$ 值 \\
\hline \multirow{5}{*}{ 日内 } & Time A & 4 & $18798.93 \pm 0.16$ & 4 & 0.09 & 0.99 & 0.45 \\
\hline & Time B & 4 & $18799.24 \pm 0.60$ & & & & \\
\hline & Time C & 4 & $18798.91 \pm 0.20$ & & & & \\
\hline & Time D & 4 & $18798.89 \pm 0.20$ & & & & \\
\hline & Time E & 4 & $18798.90 \pm 0.20$ & & & & \\
\hline \multirow{4}{*}{ 日間 } & Day 1 & 5 & $18799.07 \pm 0.01$ & 3 & 0.14 & 1.55 & 0.23 \\
\hline & Day 2 & 5 & $18799.07 \pm 0.01$ & & & & \\
\hline & Day 3 & 5 & $18798.72 \pm 0.02$ & & & & \\
\hline & Day 4 & 5 & $18799.03 \pm 0.60$ & & & & \\
\hline
\end{tabular}

先行品を 1 日 5 回 4 日間測定し, 測定質量を算出した。（二元配置の分散分析） 
表 2 還元処理した際の各製剤の測定質量 $(n=6)$

\begin{tabular}{cccccc}
\hline \hline 還元処理 & 先行品 & バイオ後続品 $\mathrm{A}$ & バイオ後続品 $\mathrm{B}$ & バイオ後続品 $\mathrm{C}$ & バイオ後続品 $\mathrm{D}$ \\
\hline \multirow{2}{*}{ 無 } & 18798.96 & 18799.05 & 18799.05 & 18799.05 & 18799.04 \\
& \pm 0.02 & \pm 0.05 & \pm 0.07 & \pm 0.07 & \pm 0.05 \\
\hline \multirow{2}{*}{ 有 } & 18802.19 & 18802.65 & 18802.65 & 18802.46 & 18802.69 \\
& \pm 0.47 & \pm 0.11 & \pm 0.07 & \pm 0.16 & \pm 0.11 \\
\hline
\end{tabular}

(参考) 還元型フィルグラスチム 製剂の理論質量

\begin{tabular}{cc}
\hline \hline 還元数 & 理論質量 \\
\hline 0 & 18798.61 \\
1 & 18800.63 \\
2 & 18802.64 \\
\hline
\end{tabular}

フィルグラスチム製剤を DTT 処理にて 45 分間還元処理し，ピーク 1 に相当する 保持時間でデコンボリューションすることにより，測定質量を算出した．ジスル フィド結合を還元すると水素が 2 個付加されることになる. DTT: dithiothreitol

(A) ピーク

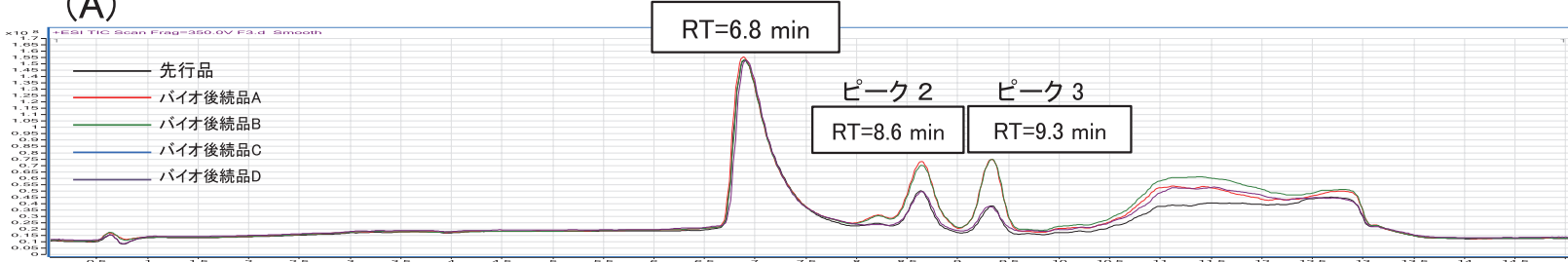

(B)

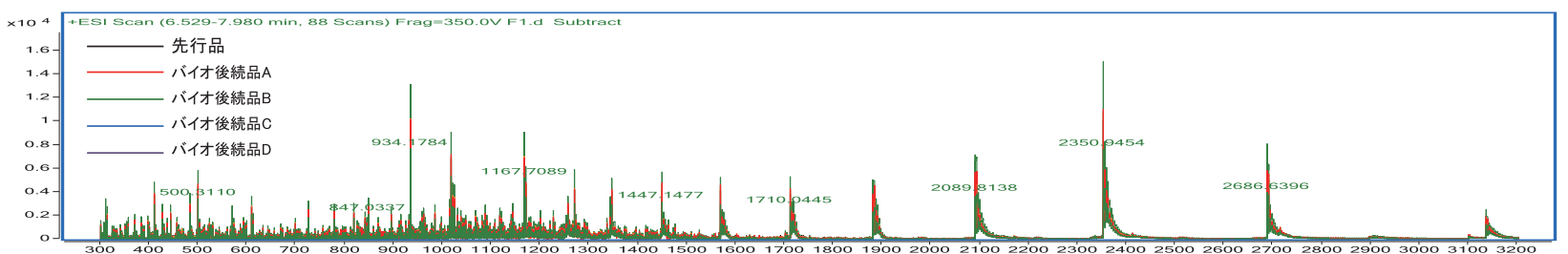

(C)

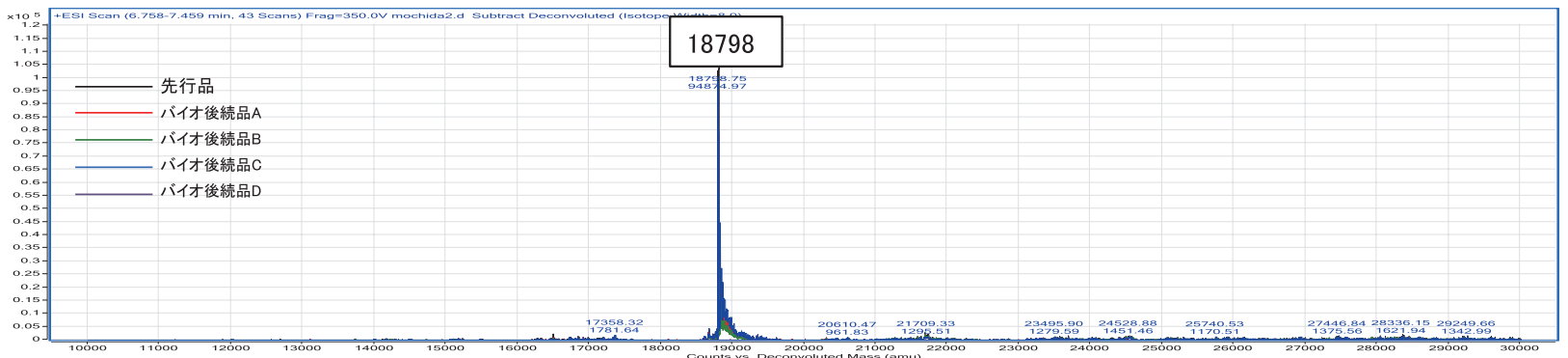

図 2 フィルグラスチム製剤のクロマトグラム

先行品およびバイオ後続品を $\mathrm{m} / \mathrm{z}=300-3200$, Fragmenter: $350 \mathrm{v}$ で質量分析した.（A）トータルイオンクロマトグラム, (B) RT=6.8 minにおけるマススペクトル，（C）デコンボリューション結果. RT: retention time

\section{4. 主成分ピークの解析}

先行品およびバイオ後続品 $\mathrm{A} \sim \mathrm{D}$ について，主 成分ピークのマススペクトルからデコンボリュー ションによる測定質量を求め, それぞれの製品の 測定質量について差の 95\%信頼区間を求めた（表 3). 先行品の測定質量は $18798.93 \pm 0.16$ と算出 され，バイオ後続品 $\mathrm{A} ， \mathrm{~B} ， \mathrm{C}$ および $\mathrm{D}$ の測定質 量は，それぞれ $18799.20 \pm 0.43 ， 18799.25 \pm 0.59$, $18799.28 \pm 0.58$ および $18799.30 \pm 0.59$ であった.
表 3 先行品とバイオ後続品の測定質量と平均值の差 $95 \%$ 信頼区間 $(\mathrm{n}=4)$

\begin{tabular}{lcc}
\hline \hline \multicolumn{1}{c}{ 製剤名 } & 測定質量 & 差の 95\%信頼区間 \\
\hline 先行品 & $18798.93 \pm 0.16$ & - \\
バイオ後続品 $\mathrm{A}$ & $18799.20 \pm 0.43$ & $-0.421 \sim 0.956$ \\
バイオ後続品 B & $18799.25 \pm 0.59$ & $-0.369 \sim 1.009$ \\
バイオ後続品 C & $18799.28 \pm 0.58$ & $-0.344 \sim 1.034$ \\
バイオ後続品 D & $18799.30 \pm 0.59$ & $-0.316 \sim 1.061$ \\
\hline
\end{tabular}

各製剤の主成分のデコンボリューション結果から算出された測 定質量から, 先行品とバイオ後続品の平均值の差 $95 \%$ 信頼区 間を算出した。 
また, 差の信頼区間については, 最も差が大きかっ たもので- 0.316〜1.061の範囲であった.なお, フィ ルグラスチムはアミノ酸残基数 175 個で分子式は $\mathrm{C}_{845} \mathrm{H}_{1339} \mathrm{~N}_{223} \mathrm{O}_{243 \mathrm{~S}} \mathrm{~S}_{9}$ であり，分子量は 18798.61 であるこ とから，このピークをフィルグラスチムと判断した.

\section{5. 副次ピークの解析}

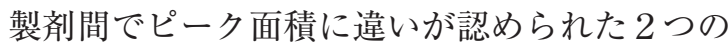
副次ピーク（ピーク 2 および 3$)$ について解析を 行った（表 4). バイオ後続品 C, D のピーク 2 および 3 の相対含有成分比は先行品と比較して有
意な差は認められなかったが, バイオ後続品 $\mathrm{A}$ およびBのピーク 2 と 3 の含有成分比は先行品 と比較して有意に高い值であった。低分子量測定 モードでの測定時においても, 高分子量測定モー ドまで含めた測定で認められたピーク 2 および 3 と同じ RT にピークが認められた（ピーク 2’およ び3）（図3A）。そこで，これらのピークに含ま れる成分のマススペクトルを確認したところ, ピーク 2, ピーク 3’ の測定質量の差はどれも 44 となった。 また，マススペクトルの形状が等間隔 にピークが現れる特徴的な形をしていた（図3B,

表 4 先行品とバイオ後続品における副次ピーク（ピーク 2 およびピーク $3 ）$ の含有成分比 $(\mathrm{n}=6)$

\begin{tabular}{ccccc}
\hline \hline 製剂名 & 含有成分比 $($ ピーク 2) & 相対標準偏差 $(\%)$ & 含有成分比 $($ ピーク 3) & 相対標準偏差 $(\%)$ \\
\hline 先行品 & $18.9 \pm 0.7$ & 3.9 & $12.8 \pm 0.8$ & 6.2 \\
\hline バイオ後続品 & & & & \\
A & $28.1 \pm 0.1 * * *$ & 0.3 & $24.5 \pm 1.8 * * *$ & 7.4 \\
B & $27.2 \pm 1.0 * *$ & 3.6 & $25.3 \pm 2.0 * * *$ & 7.7 \\
C & $18.8 \pm 0.6$ & 3.3 & $14.5 \pm 1.0$ & 6.7 \\
D & $19.2 \pm 0.6$ & 3.0 & $13.6 \pm 0.7$ & 5.0 \\
\hline
\end{tabular}

各製剂に扔ける含有成分比拉よび相対標準偏差を求めた，含有比はトータルイオンクロマトグラムよりピーク 2, ピーク 3 のピーク 面積をピーク 1 のピーク面積で除した（Dunnett の多重比較検定， $* * * P<0.001)$.

(A)

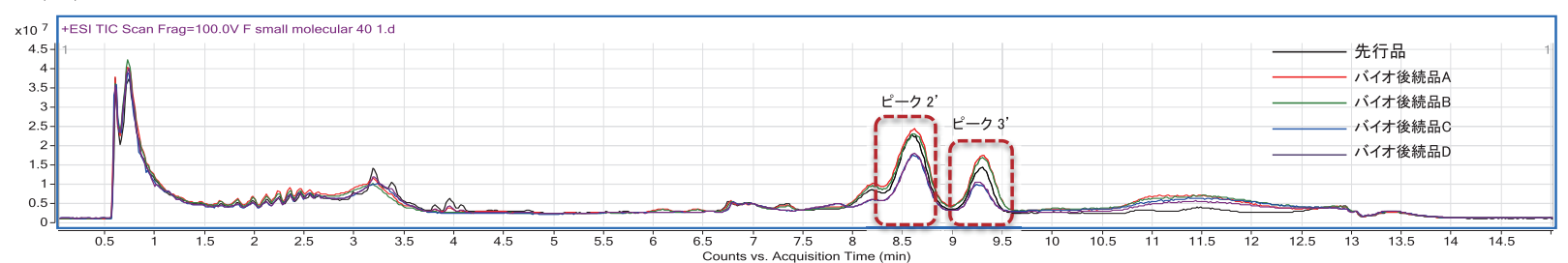

(B)

\begin{tabular}{|c|c|}
\hline 3価イオン \\
$\mathrm{m} / \mathrm{z}$ の差 $=14.68$
\end{tabular}$\quad \begin{gathered}\text { Counts vs. Acquisition Time (min) } \\
\text { 2価イオン } \\
\mathrm{m} / \mathrm{z} \text { の差 }=22.01\end{gathered}$

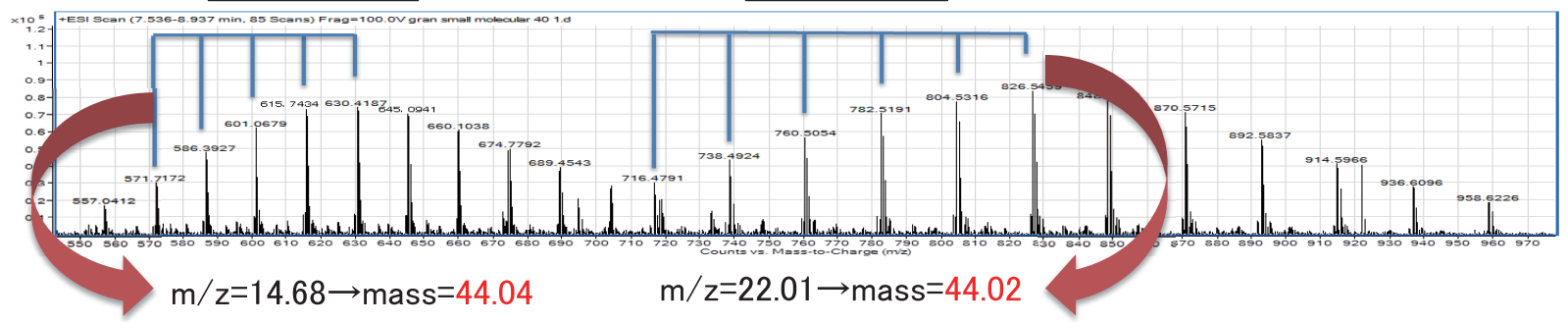

(C)

z=14.68 $\rightarrow$ mass $=44.04$

$\mathrm{m} / \mathrm{z}=22.01 \rightarrow$ mass $=44.02$

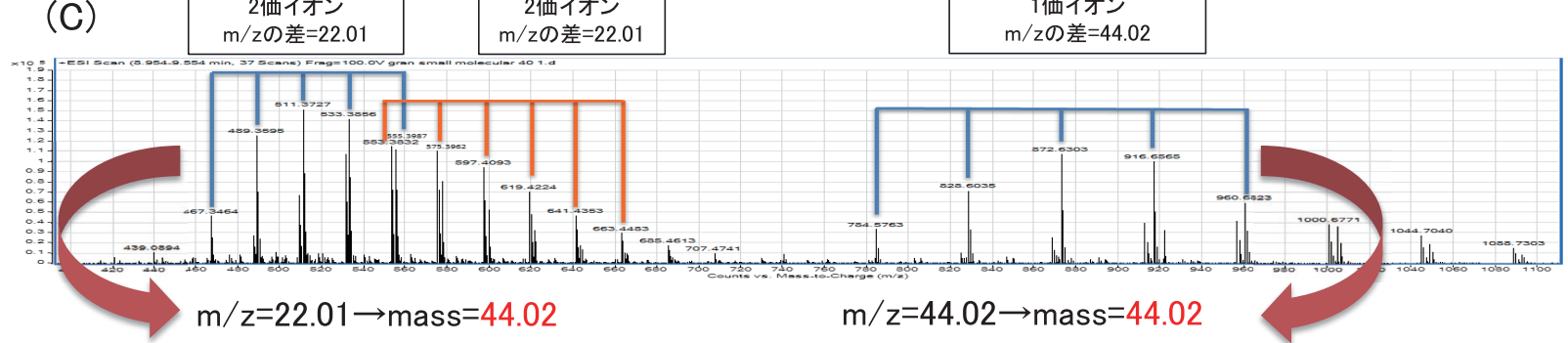

図 3 フィルグラスチム製剤のマススペクトル

先行品およびバイオ後続品を $\mathrm{m} / \mathrm{z}=100-1700$, Fragmenter: $100 \mathrm{v}$ で質量分析した.（A）トータルイオンクロマトグラム，（B）ピーク 2' のマススペクトル，（C）ピーク 3’のマススペクトル． 
3C). 試薬用ポリソルベートでも同様に確認した ところ, 質量差 44 のマススペクトルを得られた (data not shown).

\section{考察}

今回分析に用いた四重極飛行時間型質量分析計 LC/QTOF-MS について, 機器の再現性および正 確性を確認するためにフィルグラスチム先行品を 用いて日内変動拉よび日間変動を確認した。 LC/ QTOF-MS 法では 1 日 5 回の測定を 4 日間検討した ところ, 変動は認められなかった，従来のペプチ ドマッピング等での解析では, タンパク質をトリプ シン等で消化して解析を行う. ${ }^{9}$ 10) 従って, もともと 存在する小さな分解の有無を解析することが難し い.また，消化のプロセスの差により結果に影響 が出ることが考えられる．LC/QTOF-MS 法は，消 化を必要としない. Agilent 6550 iFunnel Q-TOF LC/ MS システムは 10,000 以上の分解能を有し, $\mathrm{m} / \mathrm{z}$ : 921，1221 のリファレンスを同時に流して常に補正 することで，測定誤差は $0.0005 \%$ 以内と報告され ている. ${ }^{11-133}$ 従って, 検出された $\mathrm{m} / \mathrm{z}$ 值が 2,000 , 質 量が 20,000 程度となるフィルグラスチムの質量分 析は十分に可能である. 以上より, 本分析機器に よるフィルグラスチム質量分析は再現性および正 確性の担保できる測定系であると考えられた。

ジスルフィド結合は, タンパク質が高次構造を 成し機能を発揮する上で重要である，LC/QTOFMS を用いた本手法において，ジスルフィド結合 の有無にかかわる質量差を測定できるのか検討す るため, フィルグラスチムを還元処理し分析を 行った。フィルグラスチムは糖鎖が存在せず，ジ

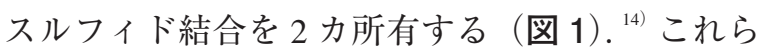
が完全に還元された場合の理論質量は, 水素原子 量を 1.008 として, $18798.61+4 \times 1.008=18802.64$ である.今回, DTTを用いて還元処理したところ， 先行品の還元後の測定質量は $18802.19 \pm 0.47$ で あった．また，同様の結果はバイオ後続品 $\mathrm{A} \sim \mathrm{D}$ でも確認された，従って，LC/QTOF-MSによる 分析は，フィルグラスチム製剤を還元処理した際 のジスルフィド結合の質量差も検出できた。この ことは, LC/QTOF-MS が今後増加するバイオ医
薬品の微細構造変化を検出できることを示してお り，バイオ医薬品の製剤間での糖鎖修飾の違いな どの測定への応用が期待できる.

LC/QTOF-MS 法を用いて，フィルグラスチム 製剤の先行品とバイオ後続品の比較解析を実施し た。トータルイオンクロマトグラムを比較した結

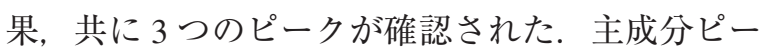
ク（ピーク 1）のそれぞれの測定質量は，デコン ボリューション解析の結果，すべて同じであると 判断された.さらに, 先行品と後続品の測定質量, RT およびクロマトグラムの形状から, 先行品と バイオ後続品 $\mathrm{A} \sim \mathrm{D}$ に確認されたピーク 1 は主成

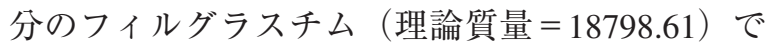
あり, 先行品とバイオ後続品の含有する主成分は ジスルフィド結合の有無を含めて同質であると考 えられた。

トータルイオンクロマトグラムにおける 2つの 副次ピーク（ピーク 2 および 3 ）について先行品 と比較したところ, バイオ後続品 C と D はどち らのピークも先行品と同等のピーク面積となった が, バイオ後続品 $\mathrm{A}$ および $\mathrm{B}$ の場合, いずれのピー クにおいても先行品よりもピーク面積が大きくな り，表 4 に示すように含有成分比についても先行 品と比較して有意に高かった．低分子量測定モー ドを検討したところ, 高分子量測定モードと同じ RT に同様のピーク（ピーク 2’および 3'）が確認 され，それぞれのマススペクロルから各質量を算 出すると，各ピーク間での測定質量差がすべて 44 となった。フィルグラスチムの添付文書に記 載のある添加物の 1 つであるポリソルベート 80 の繰り返し構造の質量が 44 であること（図 4),

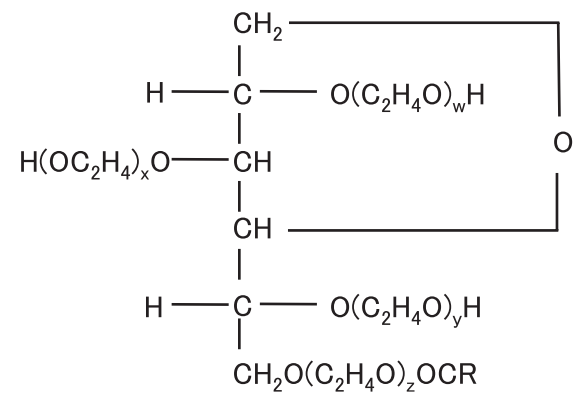

図 4 ポリソルベートの構造式

$\mathrm{w}+\mathrm{x}+\mathrm{y}+\mathrm{z}=$ 約 20 である. $\mathrm{RCO}^{-}$はポリソルベート 80 では 主としてオレイン酸 $\left(\mathrm{CH} 3\left(\mathrm{CH}_{2}\right)_{7} \mathrm{CH}=\mathrm{CH}\left(\mathrm{CH}_{2}\right)_{7} \mathrm{CO}^{-}\right)$. ただし，その他の脂肪酸も含む. 
繰り返し構造が得られたマススペクトルの形状が 等差間隔のピークを示したこと, 試薬用ポリソル ベートでも質量差 44 のマススペクトルを得られ たことを考慮すると, このピークはポリソルベー ト 80 であることが示唆された. 先行品およびバ イオ後続品の添付文書によると, バイオ後続品 $\mathrm{A}$ と $\mathrm{B}$ は, 先行品およびバイオ後続品 C と D と比 較して添加剤のポリソルベート 80 の量が多いこ とが記載されており（グラン注射液添付文書改訂 第 20 版，協和発酵キリン株式会社，2014；フィ ルグラスチム BS 注添付文書改訂第 5 版, 日本化 薬株式会社，2014；フィルグラスチム BS 注添付 文書改訂第 2 版, 持田製薬株式会社, 2014）ピー ク面積比とポリソルベート 80 の含有量比は一致 しなかったが, そのピーク面積比と含有量比の傾 向は今回の結果とも一致している，LC/QTOF-MS 法は主成分のみならず，添加物の比較にも有用で あることが示唆された。

以上，LC/QTOF-MS を用いたフィルグラスチ ム製剤の解析により，フィルグラスチム先行品と そのバイオ後続品にはジスルフィド結合も含め, 主たる成分に差異がないことが定性的に示され た. LC/QTOF-MS 法は，高分子医薬品を定性解 析する上で再現性が高く, 有用な手段であること が示唆された.

\section{謝 辞}

本研究の一部は, 国立研究開発法人日本医療研 究開発機構 (AMED) の【医薬品等規制調和・ 評価研究事業】および JSPS 科研費の支援を受け て実施した。

\section{利益相反}

開示すべき利益相反はない.

\section{引用文献}

1） 2009年 3 月, 薬食審査発第0304007号, 厚生労働 省医薬食品局審査管理課長通知「バイオ後続品 の品質・安全性・有効性確保のための指針」(厚
生労働省).

2) Schiestl M, Stangler T, Torella C, Cepeljnik T, Toll H, Grau R, Acceptable changes in quality attributes of glycosylated biopharmaceuticals, Nat Biotechnol, 2011, 29, 310-312.

3）石井明子, 原園 景, 川崎ナナ, バイオ後続品／ バイオシミラーに関する国内外の規制動向と品 質評価, Pharm Tech Japan, 2013, 29, 23-42.

4） 2009 年 3 月, 薬食審查発第0304004号, 厚生労働 省医薬食品局長通知「バイオ後続品の承認申請 について」(厚生労働省).

5） 2011 年 3 月 24 日, 厚生労働省告示第65号, 第十六 改正日本薬局方 (厚生労働省).

6) Raju TS, Terminal sugars of Fc glycans influence antibody effector functions of IgGs, Curr Opin Immun, 2008, 20, 471-478.

7) Kanda Y, Yamane-Ohnuki N, Sakai N, Yamano K, Nakano R, Inoue M, Misaka H, Iida S, Wakitani M, Konno Y, Yano K, Shitara K, Hosoi S, Satoh M, Comparison of cell lines for stable production of fucose-negative antibodies with enhanced ADCC, Biotechnol Bioeng, 2006, 94, 680-688.

8）木村康浩, 大浜 修, 土井穂波, 柴田ゆうか, 木平 健治, 注射用セファゾリンナトリウム製剤の先 発医薬品と後発医薬品における品質比較, 医療 薬学, 2008, 34, 573-577.

9) Jones MD, Merewether LA, Clogston CL, Lu HS, Peptide map analysis of recombinant human granulocyte colony stimulating factor: elimination of methionine modification and nonspecific cleavages, Anal Biochem, 1994, 216, 135-146.

10) Lu HS, Boone TC, Souza LM, Lai PH, Disulfide and secondary structures of recombinant human granulocyte colony stimulating factor, Arch Biochem Biophys, 1989, 268, 81-92.

11) Zhou JL, Qi LW, Li P, Herbal medicine analysis by liquid chromatography/time-of-flight mass spectrometry, J Chromatogr A, 2009, 1216, 7582-7594.

12) Lacorte $S$, Fernandez-Alba AR, Time of flight mass spectrometry applied to the liquid chromatographic analysis of pesticides in water and food, Mass Spectrom Rev, 2006, 25, 866-880.

13) Ferrer I, Thurman EM, Fernández-Alba AR, Quantitation and accurate mass analysis of pesticides in vegetables by LC/TOF-MS, Anal Chem, 2005, 77, 2818-2825.

14） 2013年 1 月, フィルグラスチム審査報告書（独 立行政法人医薬品医療機器総合機構). 